Saito, T. \& Arai, K. (1958b). Bull. Jap. Soc. sci. Fish. 23, 579.

Saito, T., Arai, K. \& Yajima, T. (1959). Nature, Lond., 184, 1415.

Steinbach, H. B. (1949). J. cell. comp. Physiol. 83, 123.

Storey, I. D. E. \& Dutton, G. J. (1955). Biochem. J. 59, 279.

Tarr, H. L. A. (1950). , J. Fish. Res. Bd Can. 7, 608.
Tarr, H. L. A. (1958). Annu. Rev. Biochem. 27, 223.

Truyuki, H., Chang, V. M. \& Idler, D. R. (1958). Canad. J. Biochem. Physiol. 36, 465.

Villar-Palasi, C. \& Larner, J. (1958). Biochim. biophys. Acta, 80, 449.

Vischer, E. \& Chargaff, E. (1948). J. biol. Chem. 176, 715.

Webster, H. L. (1953). Nature, Lond., 172, 453.

Wyatt, G. R. (1951). Biochem. J. 48, 584 .

Biochem. J. (1960) 77, 575

\title{
Carnosine-Anserine Synthetase of Muscle
}

\section{PARTIAL PURIFICATION OF THE ENZYME AND FURTHER STUDIES OF $\beta$-ALANYL PEPTIDE SYNTHESIS*}

\author{
BY J. J. STENESH AND T. WINNICK \\ Weizmann Institute of Science, Rehovoth, Israel
}

(Received 22 March 1960)

Previous papers of this series (Winnick \& Winnick, 1958, 1959 $a, 1960$ ) have dealt with the general properties of carnosine-anserine synthetase, an enzyme which promotes the condensation of $\beta$-alanine with either L-histidine or 1-methylhistidine at neutral $\mathrm{pH}$, in the presence of mag. nesium ions and adenosine triphosphate. The procedure for preparing carnosine-anserine synthetase involved ethanol fractionation of an extract of chick pectoral muscle. This method was employed by Kalyankar \& Meister (1959) in their enzymic synthesis of a serios of $\beta$-alanyl and $\gamma$-aminobutyryl peptides of histidine and various histidine derivatives.

Since a number of questions could not be answered satisfactorily with the crude enzyme, and in view of the current dearth of information relative to the biosynthesis of natural peptides, it was of interest to undertake the further purification and characterization of carnosine-anserine synthetase. Difficulties were encountered owing to the instability of the enzyme, and the study of the mechanism of peptide bond synthesis has been further complicated by the persistence of inter. fering enzymes in the partially purified proparation. However, certain properties of the latter have been established.

\section{EXPERIMENTAL}

\section{Materials}

DL-[1-14C]Histidine, DL-1-methyl[1-14C]histidine, DL-1ethyl[1. $\left.{ }^{14} \mathrm{C}\right]$ histidine, and $\mathrm{L}-\left[{ }^{2} \mathrm{H}\right]$ carnosine (tritiated) were preparations previously described (Winnick \& Winnick,

* Part 3: Winnick \& Winnick (1960).
1958, 1959a). [ $\left.{ }^{32} \mathrm{P}\right]$ Ortho- and [ $\left.{ }^{32} \mathrm{P}\right]$ pyro-phosphate were products of The Radiochemical Centre, Amersham, Bucks. Nucleotides were obtained from Sigma Chenical Cin., St Louis, Mo., and crystalline ribonuclease from Worthington Biochemical Corp., Freehold, N.J. DL-1-Methylhistidine, L-carnosine and DL-anserine were obtained from the California Foundation for Biochemical Research, Los Angeles.

\section{Purification of carnosine-anserine synthetase}

Ethanol step. The method described by Winnick \& Winnick $(1958,1959 a)$ was modified in two details. The minced pectoral muscle was homogenized in a Waring Blendor $(220 \mathrm{v})$, instead of with a Potter homogenizer. The tissue was blended (at half the rated voltage), first for $1 \frac{1}{\mathrm{~g}} \mathrm{~min}$. with $200 \mathrm{ml}$. of the buffer $/ 100 \mathrm{~g}$. of muscle, and then for another $\frac{1}{2} \mathrm{~min}$. with the addition of a second $200 \mathrm{ml}$. The other change was to fractionate the muscle extract between 20 and $60 \%(v / v)$ ethanol, instead of 25 and $65 \%$.

Acetome step. As in the ethanol procedure, all operations were performed in a cold room $\left(0-4^{\circ}\right)$. The precipitate from the ethanol stage was dissolved in $0.04 \mathrm{M}-2$-amino-2hydroxymethylpropane-1:3-diol (tris)-HCl buffer, $\mathrm{pH} 7 \cdot 4$, by using $130 \mathrm{ml}$. for each $100 \mathrm{~g}$. of the original muscle. This solution (containing about $20 \mathrm{mg}$. of protein $/ \mathrm{ml}$.) was immersed in an ico-salt bath. Acetone, to a concentration of $28.5 \%(\nabla / v)$, was added with stirring over a $10 \mathrm{~min}$. period, during which the temperature of the solution fell to $-5^{\circ}$. The precipitate was collected by centrifuging for $4 \mathrm{~min}$. at $600 \mathrm{~g}$. After draining off the supernatant phase as complotely as possible, the precipitate was stirred briefly with a quantity of tris buffer equal to one-third of the original volume. The turbid suspension was centrifuged $(3 \mathrm{~min}$., $9000 \mathrm{~g}$ ) to remove denatured protein. The resulting solution contained about $15 \mathrm{mg}$. of protein $/ \mathrm{ml}$. The next stage was performed without delay.

Calcium phosphate step. Again all operations were done in the cold. The method of Tiselius, Hjertin \& Levin (1956) 
was used to prepare calcium phosphate. The latter was suspended in mM-sodium phosphate (pH 6.8) and stored at $0^{\circ}$. Before use, it was centrifuged, washed with $0.04 \mathrm{M}$ tris buffer, and suspended in this same medium at a concentration of about $120 \mathrm{mg}$. of calcium phosphate $/ \mathrm{ml}$. Two volumes of gel were added to the carnosine-anserine syn. thetase (CAS) solution derived from the previous step. After standing for 20 min., the suspension was centrifuged $(3 \mathrm{~min} ., 5000 \mathrm{~g}$ ), and the supernatant solution was discarded. A volume of $0.01 \mathrm{~m}$-potassium phosphate ( $\mathrm{pH} 7.4$ ) equal to that of the original enzyme solution was added to the gel. The latter was stirred occasionally during a $20 \mathrm{~min}$. period, and then centrifuged. The clear supernatant solution was retained. This eluate, containing approx. $0.3 \mathrm{mg}$. of protein and 0.04-0.06 enzyme unit/ml., was used in all experiments except when otherwise indicated.

\section{Assay methods}

Standard measurement of dipeptide synthesis. The method used (Winnick \& Winnick, 1959a, 1960), was based upon the destruction by ninhydrin of excess of free [carboxy ${ }^{14} \mathrm{C}$ ] histidine (or histidine analogues) after incubation at $37^{\circ}$, and then measurement of radioactivity in the surviving [14 C]peptide. A slightly larger volume, $1 \mathrm{ml}$., was used for the incubation mixture, and, unless otherwise stated, the latter contained $2 \mu$ moles of ATP, $2 \mu$ moles of $\mathrm{Mg}^{2+}$ ions, $1 \mu$ mole of $\beta$-alanine, $1.3 \mu$ moles of DL-[1-14 C]histidine, $0.02-$ 0.03 unit of enzyme and $0.04 \mathrm{M}$-tris buffer, $\mathrm{pH} \mathrm{7.4}$. One unit of CAS activity is defined as the amount which synthesizes $1 \mu$ mole of dipeptide/hr.

Incorporation of $\left[{ }^{38} \mathrm{P}\right]$ orthophosphate and pyrophosphate into adenosine triphosphate. The reaction mixture was that of the preceding paragraph, except that labelled histidine was replaced by radioactive phosphate (of specified molarity). After incubation for $1 \mathrm{hr}$. at $37^{\circ}$, the reaction was stopped by adding $1 \mathrm{ml}$. of $0.5 \mathrm{M}$-perchloric acid. The precipitated protein was removed by centrifuging. To $1.5 \mathrm{ml}$. of the supernatant solution was added $0.2 \mathrm{ml}$. of acidwashed Norit A charcoal suspension $(0.1 \mathrm{~g} . / \mathrm{ml}$. of water). The mixture was stirred intermittently during $30 \mathrm{~min}$. to facilitate adsorption of nucleotide. The charcoal was then sedimented and washed three times with $3 \mathrm{ml}$. of $0.05 \mathrm{M}$ perchloric acid. It was transferred with $2 \mathrm{ml}$. of water to a steel planchet, and, after drying, the radioactivity was measured in a mica-window Geiger counter. Less than $0.05 \%$ of the initial inorganic ${ }^{82} \mathrm{P}$ was retained by the charcoal after the above treatment.

Other analyses. Protein concentration was determined by the method of Lowry, Rosebrough, Farr \& Randall (1951). Ribonucleic acid (RNA) was measured by the orcinol method of Drury (1948).

\section{RESULTS}

Purification of carnosine-anserine synthetase. The values given in Table 1 are typical of a large number of preparations made with $100-200 \mathrm{~g}$. batches of chick pectoral muscle from 3-5-week-old chicks. Less than $0.5 \%$ of the original protein remained at the final stage, but a substantial part of the enzyme activity was retained. Assays of the crude extract were inaccurate, and the activity of the enzyme at this stage was probably depressed by product inhibition, i.e. by the high concentration of dipeptides present (Winnick \& Winnick, 1959a). However, it can be concluded that about 100 -fold purification was achieved. A number of other isolation techniques, including precipitation at acid pH, chromatography, electrophoresis, salt fractionation, precipitation with metals and various reagents, and different types of adsorbents and eluting agents, were all unsuccessful, owing in considerable degree to the marked instability of the enzyme. The addition of a variety of reagents (sulphydryl compounds, cyanide, sucrose, metal ions, different buffers, $\beta$-alanine, ATP) at different stages of the procedure had no favourable effect on the stability of the enzyme. While CAS at the ethanol stage could be stored for 1-2 weeks at $-15^{\circ}$ without significant inactivation, the acetone and calcium phosphate preparations lost much of their activity in a few days at $-15^{\circ}$, and in $24 \mathrm{hr}$. at $0^{\circ}$.

Properties of the partially purified enzyme. The protein eluted from calcium phosphate gel was heterogenous when analysed by paper electrophoresis. It contained about $4 \%$ of ribonucleic acid, but there is no indication that the latter was a component of the enzyme molecule. As with the crude enzyme (Kalyankar \& Meister, 1959), the partly purified CAS was not significantly inactivated by preincubation for $1 \mathrm{hr}$. at $\mathrm{pH} 7.0$ and $25^{\circ}$ with crystalline ribonuclease $(20 \mu \mathrm{g}$./mg.).

The activity of the best preparations, about $0.2 \mathrm{unit} / \mathrm{mg}$. of protein, is much lower than that of purified glutathione synthetase of yeast (Snoke, 1955) or wheat (Webster \& Varner, 1955).

Most of the enzyme activity was lost upon freezedrying or upon dialysis in ethylene diaminetetra-

Table 1. Summary of purification of carnosine-anserine synthetase

$\begin{array}{ccc}\begin{array}{c}\text { Total } \\ \text { protein } \\ \text { (mg./100 g. } \\ \text { of muscle) }\end{array} & \begin{array}{c}\text { Total } \\ \text { enzyme } \\ \text { (units/l00 g. } \\ \text { of muscle) }\end{array} & \begin{array}{c}\text { Specific } \\ \text { activity } \\ \text { (unit/mg. } \\ \text { of protein) }\end{array} \\ 6700 & - & 0.0006 \\ 3900 & 10.6 & 0.0027 \\ 945 & 10.2 & 0.0109 \\ 26.5 & 3.5 & 0.132\end{array}$

Initial muscle extract

Ethanol fraction

Acetone fraction

Calcium phosphate eluate 
acetic acid-treated cellophan tubing for several hours at $0^{\circ}$. After the latter operation, activity was not restored by adding back the external solution. Stability was slightly increased by the addition of serum albumin. The enzyme lost much of its activity within a few hours outside the $\mathrm{pH}$ range of 6-8 (even at $0^{\circ}$ ) or at higher salt concentrations (0.2 M-sodium chloride). It could not be precipitated from dilute solution by acetone, even when a protein carrier was used. The inability to concentrate the CAS solution without extensive loss in activity proved a serious disadvantage in certain experiments described below.

Requirements for optimum activity. Partly purified CAS, like the crude ethanol fraction (Winnick \& Winnick, $1959 a$; Kalyankar \& Meister, 1959), promoted maximum carnosine synthesis at pH 7.4 with approx. $1.0 \mu$ mole of $\mathrm{L}$-histidine and 1-2 $\mu$ moles of $\beta$-alanine $/ \mathrm{ml}$. of incubation mixture, and with a linear reaction rate for the first hour at $37^{\circ}$. This stability at $37^{\circ}$ is surprising, in view of the above-mentioned inactivation upon storage at low temperatures.

Fig. 1 shows a rather sharp peak for optimum carnosine synthesis at 2 mM-ATP. In previous studies, less pure CAS preparations showed a broader plateau from about 2 to $7 \mathrm{~mm}$-ATP. This requirement for a higher concentration probably reflected adenylate kinase and adenosine triphosphatase activities. Adenosine diphosphate could replace ATP to a much smaller extent with the partly purified, as compared with the crude, CAS, which suggests a lower content of adenylate kinase in the calcium phosphate preparation. Also, tri-

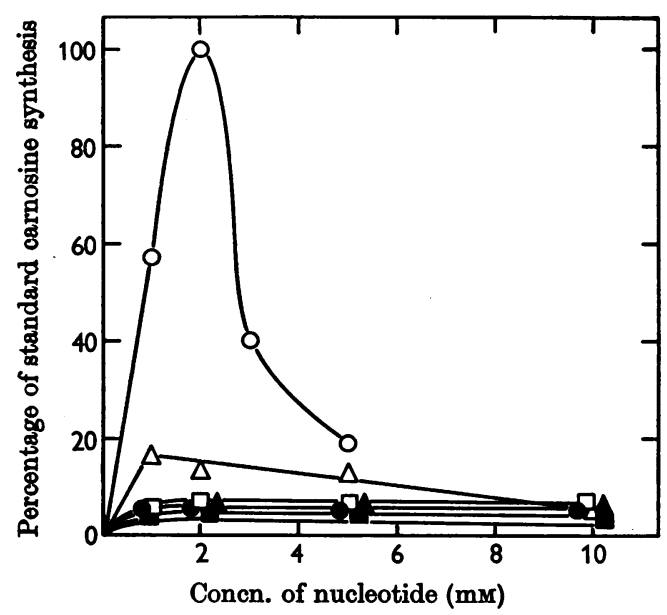

Fig. 1. Comparison of different nucleotides as activators of CAS. The values are expressed in terms of the standard assay with 2 mM-ATP, taken as 100. O, ATP; $\triangle$, ADP; $\square$, uridine triphosphate; $O$, guanosine triphosphate; $\Delta$, inosine triphosphate; $\square$, cytidine triphosphate. phosphates of guanosine, inosine, and cytidine were relatively less effective with the present enzyme.

As in earlier studies, $2 \mathrm{~mm}-\mathrm{Mg}^{2+}$ was required for optimum activity, and a higher concentration was inhibitory (Fig. 2). $\mathrm{Mn}^{2+}$ ions were able to substitute for $\mathbf{M g}^{2+}$ ions to a considerable extent, and were even more effective at low concentration. These two metals exhibited the same relationships in the case of glutathione synthetase (Snoke, 1955). Other metallic ions $\left(\mathrm{Fe}^{2+}, \mathrm{Ni}^{2+}, \mathrm{Mo}^{2+}\right)$ were much less effective. Kalyankar \& Meister (1959) reported that bivalent $\mathrm{Mn}^{2+}$ and $\mathrm{Co}^{2+}$ ions were less

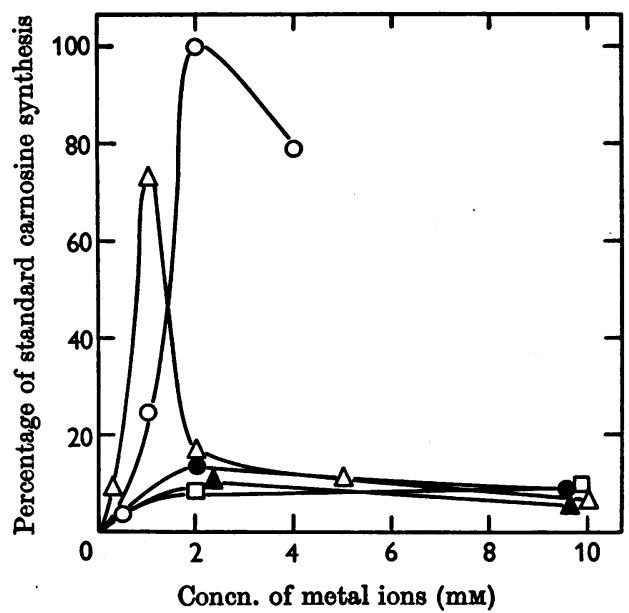

Fig. 2. Comparison of bivalent metal ions as substitutes for $\mathrm{Mg}^{2+}$ ions in dipeptide synthesis. The results are expressed in terms of the standard assay with $2 \mathrm{mM}-\mathrm{Mg}^{2+}$ taken as 100. O, $\mathrm{Mg}^{2+} ; \triangle, \mathrm{Mn}^{2+} ; \square, \mathrm{Fe}^{2+} ; 0, \mathrm{Ni}^{2+} ; \Delta$, $\mathrm{Mo}^{2+}$.

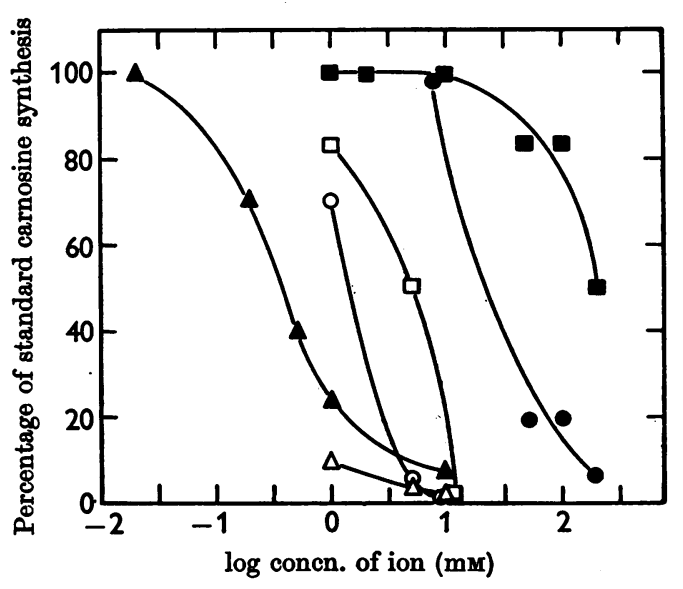

Fig. 3. Effects of various ions on CAS activity. Standard assay conditions were used (including $2 \mathrm{mM}-\mathrm{Mg}^{2+}$ ). $\mathrm{O}$, $\mathrm{Fe}^{2+} ; \triangle, \mathrm{Ni}^{2+} ; \square, \mathrm{Mo}^{2+} ; \square, \mathrm{K}^{+} ; \Delta, \mathrm{Mn}^{2+} ; 0, \mathrm{~F}^{-}$.

Bioch. 1960, 77 
than $10 \%$ as active as $\mathrm{Mg}^{2+}$ ions with the ethanol preparation.

Fig. 3 shows that $\mathrm{Mn}^{2+}$ ions did not augment the action of $\mathrm{Mg}^{2+}$ ions, but inhibited the system at concentrations as low as $0.1 \mathrm{~mm}$. It is difficult to reconcile this result with the finding that $\mathbf{M n}^{2+}$ ions could partially replace $\mathrm{Mg}^{2+}$ ions as an activator of CAS. $\mathrm{Ni}^{2+}$ ions also inhibited strongly, $\mathrm{Fe}^{2+}$ and $\mathrm{Mo}^{2+}$ were less effective inhibitors, and fluoride exerted an effect only above $10 \mathrm{~mm}$. In the case of $\mathrm{K}^{+}$ions, a mild inhibition of peptide formation was produced at between 10 and $100 \mathrm{~mm}$. A slight stimulatory effect of potassium chloride at $150 \mu \mathrm{M}$ in phosphate buffer has been observed with the crude enzyme (Kalyankar \& Meister, 1959). By contrast, $\mathrm{K}^{+}$ions were found markedly to stimulate glutathione synthesis with either acetonedried liver extracts (Johnston \& Bloch, 1951) or purified yeast enzyme (Snoke, 1955).

Substrate specificity. Previous studies with various histidine analogues and other basic $\alpha$-amino acids (Winnick \& Winnick, 1958; Kalyankar \& Meister, 1959) indicated a fairly broad specificity

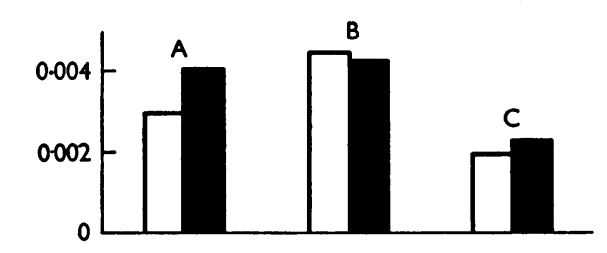

Ethanol stage

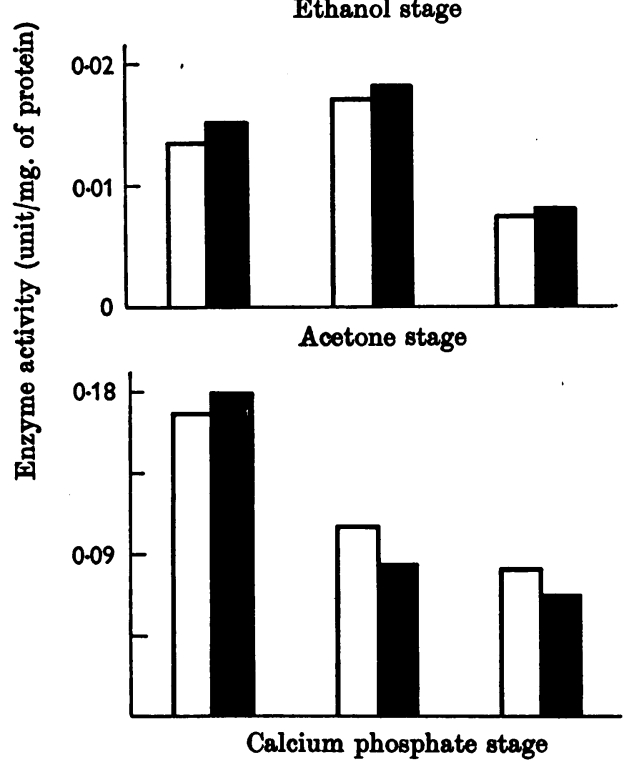

Fig. 4. Comparison of histidine substrates at different stages of purification of CAS. $\square$, Concentration of $1.3 \mathrm{mMr}-$; 1, 2.6 mM-labelled amino acid. A, Histidine; B, l-methylhistidine; C, 1-ethylhistidine.

for crude chick-muscle CAS, and raised the possibility that more than one enzyme was present. Accordingly, it was of interest to test preparations at successive stages of purification, with respect to their rates of utilization of different histidine substrates for $\beta$-alanyl peptide formation. Fig. 4 shows that CAS at the calcium phosphate stage, unlike the other preparations, was relatively less active toward 1-methylhistidine, as compared with histidine. However, more information would be required in order to conclude that anserine formation is influenced by a separate synthetase enzyme. Actually, there is evidence that anserine can arise in muscle tissue by an independent pathway, namely the methylation of carnosine by $S$ adenosylmethionine (Winnick \& Winnick, 1959b).

Transpeptidation. In connexion with the above question of the origin of anserine, it was desirable to test a third possible pathway: the transfer of a $\beta$-alanyl group from carnosine to methyl[ $\left.{ }^{14} \mathrm{C}\right]$ histidine. It can be seen in Table 2 that this re. action occurred to a much lesser extent than did the usual $\beta$-alanyl peptide synthesis. The transfer was still smaller when ethyl $\left[{ }^{14} \mathrm{C}\right]$ histidine was used with carnosine, and zero when the analogous process with $\left[{ }^{14} \mathrm{C}\right]$ histidine and anserine was tested. Results very similar to those of Table 2 were obtained with crude CAS. Unless different conditions or other enzymes are operative in vivo, it appears unlikely that transpeptidation represents a major pathway of anserine formation. It may be mentioned that purified yeast-glutathione synthetase promotes an exchange of labelled glycine with the glycine of the tripeptide, in the presence of $\mathrm{Mg}^{2+}$ ions, ATP and arsenate (Snoke \& Bloch, 1954). In this case the ratio of transfer to synthesis is $1: 11$.

Experiments on the mechanism of carnosine formation. In previous studies with crude CAS, the working hypothesis was adopted that the first step in carnosine synthesis consisted in the interaction

\section{Table 2. Attempted transpeptidation reactions with carnosine-anserine synthetase}

The assay involved incubation for $1 \mathrm{hr}$. at $37^{\circ}$ of 0.02 0.03 unit of purified CAS with $2 \mu$ moles of ATP, $2 \mu$ moles of $\mathrm{Mg}^{2+}$ ions, $2 \mu$ moles of peptide and 1.5 $\mu$ moles of labelled amino acid, all in $1 \mathrm{ml}$. of $0.04 \mathrm{M}$-tris buffer ( $\mathrm{pH} \mathrm{7.4)}$. The ninhydrin method (Winnick \& Winnick, 1960) was used to measure formation of $\left[{ }^{14} \mathrm{C}\right]$ peptide. The units are defined similarly to those for carnosine synthesis, for which the activity was 0.15 unit/mg. of protein.

Isotopic amino acid DL-Methyl[ $\left.{ }^{14} \mathrm{C}\right]$ histidine DL-Ethyl[1יa C]histidine DL- $\left[{ }^{4} \mathrm{C}\right]$ Histidine

Transfer activity (unit/mg. of protein)

Peptide

L-Carnosine L-Carnosine DL-Anserine
0.010

0.002 0.000 
of $\beta$-alanine, ATP and enzyme (E) to yield an activated form of the amino acid, with pyrophosphate as a by-product:

$$
\beta \text {-Alanine }+\mathrm{ATP}+\mathrm{E} \stackrel{\mathrm{Mg}^{2+}}{\rightleftharpoons} \mathrm{E}-\beta \text {-alanine-AMP + pyrophosphate }
$$
CAS, beceuse of a high exchenge rate which was independent of added $\beta$-alanine (Kalyankar \&

The second stage would be:

$$
\mathrm{E}-\beta \text {-alanin }-\mathrm{AMP}+\mathrm{L} \text {-histidine } \rightleftharpoons \mathrm{L} \text {-carnosin } \theta+\mathrm{E}+\mathrm{AMP}
$$

The first phase corresponds to the much-studied process of $\alpha$-amino acid activation. Some support for the involvement of pyrophosphate was the strong inhibition produced by this compound (as compared with orthophosphate) on $\beta$-alanyl peptide synthesis with crude enzyme. Fig. 5 gives very similar results for partly purified CAS.

An excess of adenosine $5^{\prime}$-phosphate (AMP) also depressed carnosine formation (Fig. 5), and ADP exerted an even stronger effect. It has already been mentioned (Fig. 1) that high concentrations of ATP inhibited carnosine synthesis. These effects of adenine nucleotides cannot at present be explained.

An indication that the overall reaction is not readily reversed was provided by incubating radioactive (tritiated) carnosine with CAS in the presence of various combinations of AMP, ATP, pyrophosphate, $\beta$-alanine and histidine. In all cases less than $1 \%$ of the total isotope was found in the $\beta$-alanine region of chromatograms. In these experiments, histidine was not resolved from the carnosine area, and the latter accounted for 98$99 \%$ of the tritium.

The incorporation of [ $\left.{ }^{32} \mathrm{P}\right]$ pyrophosphate into ATP, commonly used to characterize the $\alpha$-amino

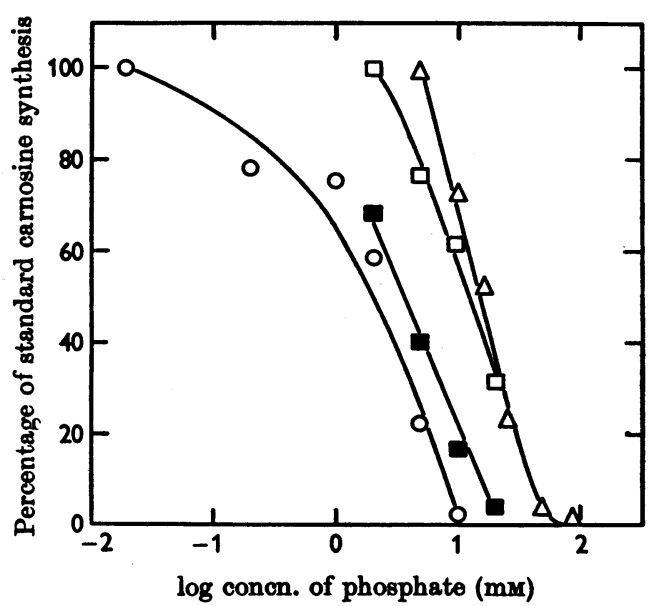

Fig. 5. Effect of phosphate compounds on CAS activity. The values are in terms of standard assay conditions, with 2 mM-ATP present. The orthophosphate concentration includes that present in the added enzyme solution. $O$, Pyrophosphate; $\triangle$, orthophosphate; $\square$, AMP; $\square$, ADP.
Meister, 1959; Winnick \& Winnick, 1960). After considerable purification, the enzyme still promoted a moderate degree of [ ${ }^{32} \mathrm{P}$ ]pyrophosphate incorporation in the absence of $\beta$-alanine. In certain experiments, as in Fig. 6, a low $\beta$-alanine concentration slightly stimulated the reaction, but this effect was not consistently reproducible and was probably not outside experimental error. [ ${ }^{32}$ P]Orthophosphate was not appreciably incorporated into ATP.

Other experiments bearing on this question, for which data are not presented, can be mentioned briefly. Preincubation of the enzyme with ATP and histidine, in order to use up traces of $\beta$-alanine that might conceivably have been present, failed to improve subsequently the $\beta$-alanine dependence of the [ $\left.{ }^{32} \mathrm{P}\right]$ pyrophosphate exchange reaction. Actually, no $\beta$-alanine could be detected upon analysis of acid extracts of the enzyme. At acid pH $(5.0$ and 6.5$)$ the incorporation of pyrophosphate into ATP was very low, and again it was not stimulated by $\beta$-alanine. In addition $\gamma$-aminobutyric acid, an analogue of $\beta$-alanine, was not effective (at $\mathrm{pH}$ 7.4).

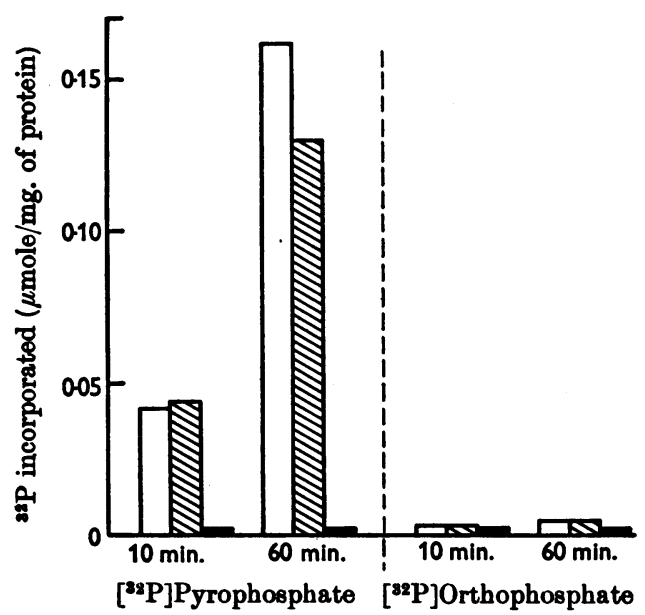

Fig. 6. Incorporation of [ [8P]orthophosphate and ['2P]pyrophosphate into ATP. The complete mixture ( $\square)$ contained, in addition to CAS: $1 \mathrm{mM}-\beta$-alanine, $2 \mathrm{mM}-\mathrm{ATP}$, $2 \mathrm{mM}-\mathrm{Mg}^{2+}$, and $1 \mathrm{~mm}$-labelled phosphate. $\mathbb{Q}, \beta$-Alanine omitted; $\square$, enzyme omitted. The activities are expressed per mg. of enzyme protein. 
Very high concentrations of $\beta$-alanine strongly inhibited the $\left.{ }^{32} \mathrm{P}\right]$ pyrophosphate exchange reaction (Fig. 7). By contrast, $\alpha$-alanine had no effect on this process.

Table 3 shows that high concentrations of fluoride likewise inhibited pyrophosphate-ATP exchange. This blockage also occurred in the presence of a large excess of $\beta$-alanine. The complete inhibition of the overall reaction by potassium fluoride resembles the results of Davis \& Novelli (1958) with extracts of peas. They found that elevated fluoride concentration strongly depressed both endogenous and $\alpha$-amino aciddependent [ $\left.{ }^{32} \mathrm{P}\right]$ pyrophosphate-ATP exchange.

In the present research, experiments were also performed with ${ }^{14} \mathrm{C}$-labelled ATP and with ATP labelled in the terminal phosphate with ${ }^{32} \mathrm{P}$, in attempts to correlate peptide-bond formation with hydrolysis of ATP, as was done for glutathione synthesis (Snoke \& Bloch, 1954). There was some

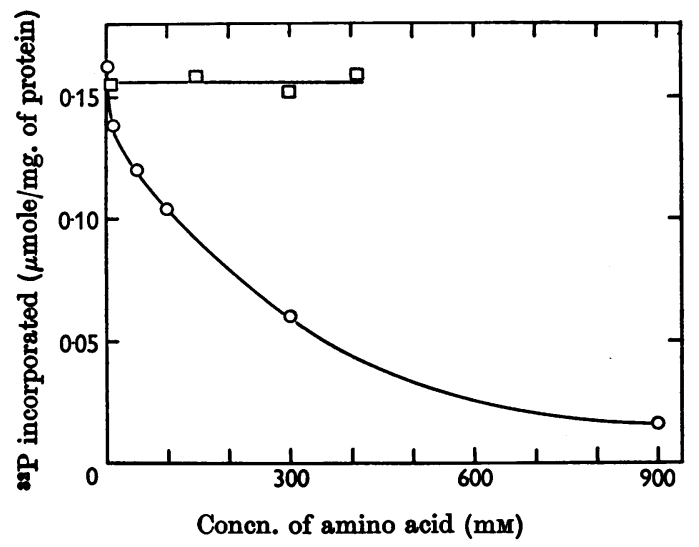

Fig. 7. Effect of high alanine concentrations on [22 P]pyrophosphato-ATP exchange. The incubation mixture contained $2 \mathrm{~mm}-\mathrm{ATP}, 2 \mathrm{~mm}-\mathrm{Mg}^{2+}, 2 \mathrm{mw}-\left[{ }^{32} \mathrm{P}\right]$ pyrophosphate, and enzyme. $O, \beta$-Alanine; $\square, \alpha$-alanine.

Table 3. Inhibition by fluoride of [32P]pyrophosphate-ATP exchange

The assay conditions were those of Fig. 7, except that 2 mM- $\beta$-alanine and various concentrations of $K F$ were present.

\begin{tabular}{|c|c|}
\hline $\begin{array}{l}\text { Concentration } \\
\text { of fluoride } \\
\text { (mM) }\end{array}$ & $\begin{array}{c}\text { Exchange } \\
\text { activity ( } \mu \text { mole of } \\
\text { [32P]pyrophosphate } \\
\text { incorporated into } \\
\text { ATP } / \mathrm{mg} \text {. of protein) }\end{array}$ \\
\hline $\begin{array}{r}0 \\
10 \\
50 \\
100 \\
200\end{array}$ & $\begin{array}{l}0.125 \\
0.095 \\
0.069 \\
0.006 \\
0.000\end{array}$ \\
\hline
\end{tabular}

indication that low concentrations of $\beta$-alanine stimulated ATP breakdown in the presence of CAS and histidine, but the available enzyme solutions were too dilute for accurate measurement of the effect.

As in the case of crude CAS (Winnick \& Winnick, $1960)$, attempts to demonstrate the formation of $\beta$-alanine hydroxamate, or an adenylate of the $\beta$-amino acid (by charcoal adsorption or paper chromatography methods), were unsuccessful. Likewise, it was not possible to detect an activated form of the enzyme, after incubation with $\beta$ alanine plus $\left[{ }^{14} \mathrm{C}\right] \mathrm{ATP}$, or with $\left[{ }^{14} \mathrm{C}\right]-\beta$-alanine and ATP. Provious experiments with synthetic $\beta$ alanine adenylate (Winnick \& Winnick, 1960) were complicated by the instability of this compound, and its ability to combine non-enzymically with histidine. However, it is of interest that Kalyankar \& Meister (1959) have been able to obtain an enzymic synthesis of ATP from [ $\left.{ }^{32} \mathrm{P}\right]$ pyrophosphate and $\beta$-alanine adenylate in the presence of $\mathrm{Mg}^{2+}$ ions and fluoride.

Three types of evidence in the present paper support the view that the observed pyrophosphate-ATP exchange was an integral part of the overall process catalysed by CAS: (1) pyrophosphate is a strong inhibitor of carnosine synthesis; (2) fluoride inhibits both the pyrophosphate-ATP exchange reaction and carnosine formation; and (3) the enzyme catalyses the exchange process at maximum rate in the absence of detectable amounts of $\beta$-alanine. This last finding is analogous to the observation made by Novelli (1959) with a glycineactivating enzyme of Photobacterium fischeri.This enzyme promoted a vigorous glycine-independent incorporation of orthophosphate into ATP.

The above facts suggest the possibility that the initial step in carnosine synthesis may involve the interaction of enzyme and ATP, rather than the activation of $\beta$-alanine. Such an interpretation would be in agreement with the observed inhibition of the exchange reaction by high concentrations of $\beta$-alanine (but not $\alpha$-alanine). However, it is felt that the available data do not justify detailed speculation on alternative mechanisms. Further studies with more active enzyme preparations are obviously required for the elucidation of the pathway of $\beta$-alanyl peptide synthesis.

\section{SUMMARY}

1. The enzyme which promotes the synthesis of carnosine and anserine from their component amino acids has been purified about 100 -fold, from an extract of chick pectoral muscle. The successive steps were fractionation with ethanol, followed by acetone, and then adsorption and selective elution of the enzyme from calcium phosphate gel. The 
purification experiments were severely hampered by the lability of the enzyme.

2. Peptide-bond formation specifically required adenosine triphosphate, and magnesium ions could be replaced to a considerable extent by manganous ions. Carnosine synthesis was not readily reversible. Pyrophosphate was strongly inhibitory, and orthophosphate less so. Although the enzyme preparation promoted [ $\left.{ }^{32} \mathrm{P}\right]$ pyrophosphate incorporation into adenosine triphosphate, a dependency upon $\beta$-alanine could not be clearly demonstrated. In fact, this process was suppressed by a high $\beta$ alanine concentration. Fluoride ions inhibited both carnosine synthesis and pyrophosphate-adenosine triphosphate exchange.

3. Attempts to detect an activated intermediate stage in carnosine synthesis were not successful.

4. $\beta$-Alanyl transfer from carnosine to 1-methylhistidine to yield anserine proceeded very slowly, as compared with direct dipeptide synthesis by the enzyme.

This research was supported by a grant from the Muscular Dystrophy Associations of America.

\section{REFERENCES}

Davis, J. W. \& Novelli, G. D. (1958). Arch. Biochem. Biophys. 75, 299.

Drury, H. F. (1948). Arch. Biochem. 19, 455.

Johnston, R. B. \& Bloch, K. (1951). J. biol. Chem. 188, 211.

Kalyankar, G. D. \& Meister, A. (1959). J. biol. Chem. 234, 3210.

Lowry, O. H., Rosebrough, N. J., Farr, A. L. \& Randall, R. J. (1951). J. biol. Chem. 193, 265.

Novelli, G. D. (1959). Biochim. biophys. Acta, 33, 261.

Snoke, J. E. (1955). J. biol. Chem. 213, 813.

Snoke, J. E. \& Bloch, K. (1954). In Glutathione, p. 129. Ed. by Colowick, S. P. et al. New York: Academic Press Inc.

Tiselius, A., Hjertin, S. \& Levin, O. (1956). Arch. Biochem. Biophys. 65, 132.

Webster, G. C. \& Varner, J. E. (1955). Arch. Biochem. Biophys. 55, 95.

Winnick, R. E. \& Winnick, T. (1958). Bull. Soc. Chim. biol., Paris, 40, 1727.

Winnick, R. E. \& Winnick, T. (1959a). Biochim. biophys. Acta, 31, 47.

Winnick, R. E. \& Winnick, T. (1960). Biochim. biophys. Acta, 37, 214.

Winnick, T. \& Winnick, R. E. (1959b). Nature, Lond., 183, 1466.

Biochem. J. (1960) 77, 581

\title{
The Fractionation of Urine Colloids on Anion-Exchange Cellulose
}

\author{
BY A. J. ANDERSON,* M. H. LEPPER AND R. J. WINZLER \\ Departments of Biological Chemistry and Preventive Medicine, University of Illinois College \\ of Medicine, Chicago, Illinois, U.S.A.
}

(Received 30 March 1960)

Urine contains a complex mixture of highmolecular-weight material, some components of which may be derived from the serum through a process of glomerular filtration or secretion and some of which may be derived from the urinary tract itself. Information about the nature of the urine colloids, however, has lagged considerably behind the knowledge of those in serum. Three main classes of high-molecular-weight compounds in urine have been recognized: proteins, glycoproteins and mucopolysaccharides. The presence of protein in urine was recognized as early as 1895 by Möerner and urine proteins have since been studied extensively by many workers, particularly Rigas \& Heller (1951) and McGarry, Schon \& Rose (1955). The variation in the amount of heat-coagulable protein in urine with several diseases, particularly

* Present address: Department of Pathology, Royal National Orthopaedic Hospital, Stanmore, Middlesex, England. the nephrotic syndrome, is well known (Heremans, 1958).

The term 'glycoprotein' is used to indicate components containing appreciable amounts of hexosamine, which can be liberated only after vigorous hydrolysis. Glycoproteins generally also contain hexose and sialic acid, with little or no uronic acids. Urinary fractions presumed to contain glycoproteins have been studied by Boyce, King, Little \& Artom (1958), Boyce \& King (1959) and King, Boyce, Little \& Artom (1958). One normal urinary glycoprotein, first described by Tamm \& Horsfall (1950), has been extensively characterized with respect to its composition and physical properties (Tamm \& Horsfall, 1952; Tamm, Bugher \& Horsfall, 1955; Porter \& Tamm, 1955). Anderson (1954) has reported the isolation of two heterogeneous glycoprotein fractions from normal urine. Application of a method for estimating one of these fractions (Anderson \& Maclagan, 1955) 